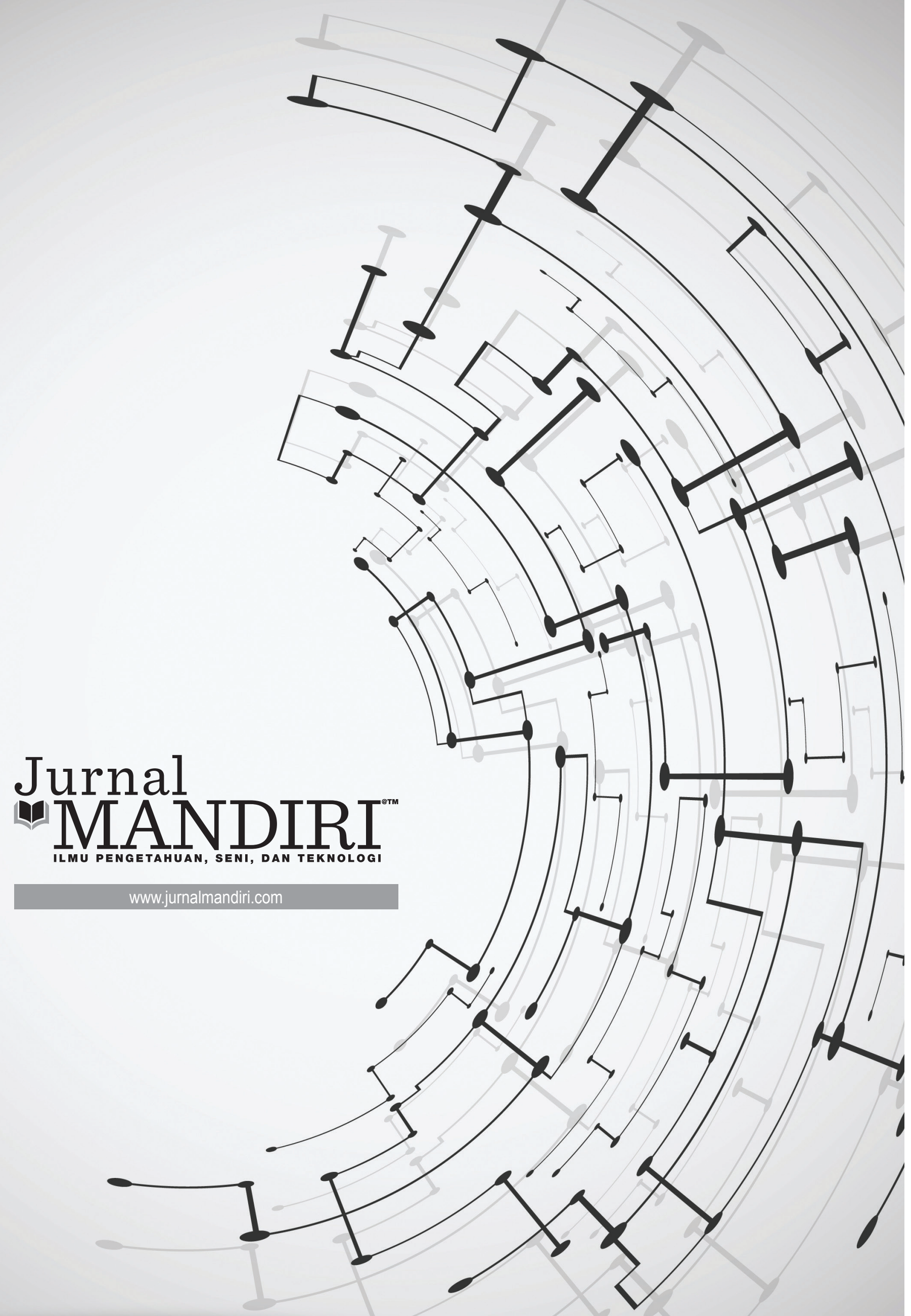


ISSN : 2580-3220, E-ISSN : 2580-4588

J. Mandiri., Vol. 1, No. 2, Desember 2017 (290 - 309)

(C2017 Lembaga Kajian Demokrasi

dan Pemberdayaan Masyarakat (LKD-PM)

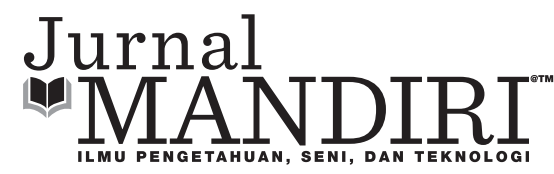

\title{
ANALISIS SUMBER DAN PENGGUNAAN DANA DALAM UPAYA PENINGKATAN \\ LIKUIDITAS DAN KEMAMPULABAAN \\ PADA PT BANK X (PERSERO)
}

\author{
Sutiman \\ Universitas Pamulang \\ dosen01673@unpam.ac.id
}

\begin{abstract}
ABSTRAK
Sektor Perbankan saat ini menjadi amat penting peranannya dalam proses pembangunan. Oleh karena itu PT Bank X (Persero) yang bergerak dalam Jasa Perbankan adalah menghimpun dana dari masyarakat sebanyak mungkin dan mengelolanya agar dapat digunakan sebagai salah satu modal pembangunan. Namun dalam perkembangannya dewasa ini tidaklah mudah bagi bank untuk dapat melaksanakan fungsinya tersebut. Terlebih lagi sejak diadakannya deregulasi di bidang keuangan, moneter dan perbankan yang ditempuh melalui paket 1 Juni 1983 dan kemudian dilanjutkan dengan kebijakan 28 Oktober 1988. Penelitian ini bertujuan untuk memperoleh gambaran mengenai sumber dan penggunaan dana dalam upaya peningkatan likuiditas dan kemampulabaan. Metode Penelitian yang digunakan dalam studi ini merupakan studi kasus yang mengambil sampel PT Bank X (Persero) sebagai objek penelitian, yang meliputi penelitian kepustakaan dan penelitian lapangan dengan cara wawancara dan observasi. Landasan teori yang yang digunakan untuk mengukur tingkat Likuiditas dan kemampulabaan. Disamping itu dilakukan analisis posisi keuangan dengan menggunakan model Analisis Diskriminan untuk mengukur tingkat kebangkrutan. Hasil analisis menunjukkan bahwa Likuiditas pada tahun 1995 sebesar 101,47 persen, tahun 1996 sebesar 113,31 persen dan tahun 1997 sebesar 113,39 persen, yang berarti terjadi kenaikan dari tahun 1995 ke tahun 1996 sebesar 11,84 persen dan dari tahun 1996 ke tahun 1997 sebesar 0,08 persen. Kemampulabaan pada tahun 1995 sebesar 18,4 persen, tahun 1996 sebesar 19,36 persen dan tahun 1997 sebesar 22,61 persen, yang berarti ada kenaikan antara tahun1995 ke tahun 1996 sebesar 0,96 persen dan tahun 1996 ke tahun 1997 sebesar 3,25 persen. Analisis diskriminan dinyatakan sehat, dimana Z (Overall Indek) menunjukkan angka 3,1 yang berarti melebihi standar kebangkrutan yaitu $Z>2,99$.
\end{abstract}

Kata Kunci : likuiditas, kemampulabaan, analisis diskriminan, standar kebangkrutan. 


\section{PENDAHULUAN}

Sektor perbankan kini menjadi sangat penting peranannya dalam proses pembangunan. Bank merupakan lembaga yang berperan sebagai perantara keuangan (financial intermediary) antara pihak yang memerlukan dana dengan pihak yang kelebihan dana serta sebagai lembaga yang berfungsi memperlancar lalu lintas pembayaran baik di dalam negeri maupun luar negeri. Adapun filosofi yang mendasari kegiatan usaha bank serta peranannya tersebut adalah kepercayaan masyarakat. Oleh sebab itu peranan Bank yang utama adalah menghimpun dana dari masyarakat dan mengelolanya agar dapat digunakan sebagai salah satu modal pembangunan.

Namun dalam perkembangannya dewasa ini tidaklah mudah bagi suatu lembaga keuangan atau bank untuk melaksanakan fungsinya tersebut. Terlebih sejak diadakannya deregulasi bidang perbankan melalui paket 1 Juni 1983 dan kemudian dilanjutkan dengan adanya pakto 28 Oktober 1988, dimana pengaruh dari kebijakan tersebut adalah semakin melonjaknya pertumbahan jumlah bank di dalam negeri, perluasan jaringan kantor bank, peningkatan volume usaha dan semakin beragamnya jenis produk yang ditawarkan untuk menarik minat masyarakat.

Perkembangan di atas telah meningkatkan persaingan antar lembaga keuangan untuk memperebutkan dana yang ada dalam masyarakat. Agar bank dapat menghimpun dana sebanyak munkin, maka bank harus dapat memberikan daya tarik kepada nasabahnya, antara lain berupa rasa aman atas keselamatan dana yang dititipkannya dan memperoleh kepuasan pelayanan.

Bagi PT Bank X (Persero) dana masyarakat yang terhimpun selain memiliki arti penting juga mempunyai kerawanan apabila tidak dikelola dengan baik yang akhirnya dapat menimbulkan kerugian bagi bank. Terhadap hal ini bank harus lebih memperhatikan sumber dan penggunaan dana masyarakat yang terhimpun.

Dalam upaya meningkatkan Likuiditaas dan Profitabilitas, PT Bank X (Persero) perlu menganalisis sumber dan penggunaan dana masyarakat yang telah terhimpun. Analisis ini akan sangat berpengaruh pada keberhasilan kebijakan yang dilaksanakan terhadap perkembangan operasional dalam segala produk yang dikeluarkannya, yang pada akhirnya tujuan yang telah dicanangkan akan tercapai dengan baik. Mengingat pentingnya peranan pengelolaan terhadap dana masyarakat yang terhimpun, penulis sangat tertarik untuk membahasnya. Untuk itu penulis memilih judul penelitian “Analisis Sumber dan Penggunaan Dana Dalam Upaya Peningkatan Likuiditas Dan Kemampulabaan Pada PT BANK X (Persero)".

Tujuan penelitian adalah merupakan penyaluran hasrat keingin tahuan manusia dalam bidang keilmuan, yang dapat dicari penjelasannya secara ilmiah melalui berbagai cara uji coba dan analisa terhadap obyek yang akan diteliti. Untuk itu penulis mengadakan penelitian dengan tujuan sebagai berikut :

1. Untuk memperoleh gambaran mengenai manajemen dana pada PT Bank X (Persero), apabila dikaitkan dengan upaya peningkatan Likuiditas dan Kemampulabaan.

2. Untuk lebih dapat mendalami pengetahuan manajemen keuangan, terutama dalam praktek di dalam bidang perbankan.

3. Bagi manajemen, ungkapan hasil penelitian ini bisa memberikan manfaat praktis melalui masukan informasi kepada manajemen dalam proses pengambilan keputusan khususnya didalam sumber dana dan penggunaan dana yang ada.

4. Dari segi ilmu pengetahuan, hasil penelitian ini diharapkan dapat menambah khazanah kepustakaan pengembangan ilmiah, yang berlandaskan pada fakta penelitian.

Ruang Lingkup Pembahasan, mengenai Permasalah utama yang dihadapi perbankan secara umum adalah bagaimana mnghimpun dana dan mengelola dana yang diperoleh dengan sebaik-baiknya. Analisis yang dilakukan terhadap sumber dan penggunaan dana nanti- 
nya akan berkaitan dengan banyak hal, namun dalam penelitian ini penulis membatasi yang berkaitan dengan Likuiditas dan Kemapulabaan. Karena penulis menganggap hal ini berkaitan erat dengan manajemen dana.

Dan dalam analisis ini penulis akan membahas hal-hal mengenai :

1. Analisis likuiditas dan kemampulabaan

2. Analisis sumber dan penggunaan dana serta analisis sumber dan penggunaan modal kerja.

3. Analisis perubahan likuiditas dengan tingkat kemampulabaan.

4. Analisis diskriminan.

\section{METODE PENELITIAN}

Dalam penelitian ini metode yang digunakan penulis adalah metode deskriptis analitis dengan tehnik pengumpulan data dengan mengambil sampel pada PT Bank X (Persero) sebagai obyek penelitian sebagai berikut :

1. Penelitian Kepustakaan (Library Research) Penelitian yang bersumber dari perpustakaan dengan cara membaca buku-bu$\mathrm{ku}$, surat edaran intern, tulisan-tulisan ilmiah untuk memperoleh bahan-bahan yang berhubungan dengan obyek penelitian.

2. Penelitian Lapangan (Field Research). Dalam rangka melengkapi data dalam penyusunan penelitian ini, penulis melakukan penelitian secara langsung ke PT Bank $\mathrm{X}$ (Persero) atau lapangan guna mendapatkan data yang akurat yaitu dengan cara :

a. Wawancara (interview) bebas yaitu penulis melakukan wawancara atau interview langsung dengan para pejabat/ petugas yang berhubungan langsung dengan bagian dana, dan wawancara terpinpin yaitu dengan membawa sederetan pertanyaan lengkap dan terperinci, sehingga penulis memperoleh data dan gambaran yang jelas mengenai aktivitas yang penulis perlukan.

b. Observasi yaitu penulis mengadakan ovservasi langsung ke tempat obyek pe- nelitian, dalam hal ini dilakukan secara langsung ke unit kerja terkait yang ada hubungannya dengan pengumpulan data dan penggunaan dana yang didapat dari para nasabahnya atau poihak ke tiga.

Untuk memperoleh gambaran secara umum mengenai permasalahan yang dibahas dari penelitian ini, maka sistimatika pembahasannya dibagi menjadi lima bab yang secara garis besar mencakup :

1. Pendahuluan

Diuraikan latar belakang, tujuan penelitian, ruang lingkup pembahasan, metode penelitian dan sistimatika pembahasan.

2. Landasan Teori

Diuraikan mengenai teori yang meliputi pengertian dana bank, manajemen dana bank, manajemen pembelanjaan, laporan keuangan, sumber dan penggunaan dana, analisis likuiditas, kemampulabaan dan analisis diskriminan.

3. Materi dan Obyek Penelitian

Menguraikan sejarah singkat perusahaan, struktur organisasi, kebijakan pengumpulan dan pengerahan dana, kegiatan usaha perusahaan dan laporan keuangan tahun 1995, 1996 dan 1997

4. Hasil Analisis dan Pembahasan

Diuraikan analisis sumber dan penggunaan dana, sumber dan penggunaan modal kerja. Dan akan dibahas pula mengenai analisis perubahan likuiditas dengan tingkat kemampulabaan perusahaan dan analisis diskriminan.

5. Kesimpulan dan Saran

Diuraikan analisis sumber dan penggunaan dana dalam upaya peningkatan likuiditas dan kemampulabaan dan atas dasar kesimpulan disarankan seyogyanya lebih memperhatikan keseimbangan sumber dan penggunaan dana guna menjada kepercayaan masyarakat serta upaya mendorong upaya peningkatan likuiditas dan kemampulabaan yang selama ini telah dilakukan. 
Pengertian Umum Assets And Liability Management (Selamet Riyadi, $2003: 33$ ).

Assets and Liability Management pada dasarnya adalah merupakan suatu planning, organizing, actuating dan controlling untuk mendapatkan penetapan kebijaksanaan di biang pengelolaan :

a. Permodalan (Equity)

b. Pemupukan Dana (Funding)

c. Penggunaan Dana (Asset)

Yang satu sama lain saling terkait (koordinasi) dalam mencapai tingkat laba yang optimal dengan tingkat risiko yang telah diperhitungkan.

Ruang Lingkup Assets And Liability Management. Dilihat secara sempit :

a. Terfokus pada penyebaran fungsi Asset and

Liability Management yaitu :

$\square$ Asset Management

$\square$ Liabilkity Management

$\square$ Capital Management

b. Tujuannya adalah untuk mengoptimalkan perbedaan waktu antara pendapatan disisi asset dengan biaya bunga atas dana.

c. Penyebaran setiap tindakan management :

$\square$ Misalnya Net Interest Margin yang merupakan persentase hasil bunga terhadap total asset atau terhadap total earning asset.

$\square$ Spread yang dikehendaki atas interest yang ditetapkan.

Jika Dilihat secara luas adalah :

a. Sebagai pedoman kebijakan bank yang akan datang.

b. Peningkatan dana untuk mengakomodasikan kebutuhan yang telah direncanakan.

c. Pengalokasian dana diantara kas, aktiva produktif dan fasilitas kantor.

d. Positioning the Bank yang dapat mengadopsi peningkatan profit apakah untuk kondisi yang akan datang bisa meningkat.

\section{Ruang Lingkup Pembahasan dan Pengertian Tentang Dana.}

Pengerian Dana menurut (Jonker Sihom- bing, 1993 : 31) dalam bukunya Pengantar Funds Management Untuk Perbankan. Dana Perbankan adalah terdiri dari berbagai sumber yang secara garis besar dapat dikategorikan dalam empat kelompok yakni ; dana masyarakat (customer deposits), bantuan kredit likuiditas dari Bank Indonesia, dana mahal yang doibeloi di pasar uang (purchased funds) dan dana sendiri (equity).

Dana merupakan dasar utama untuk kelangsungan hidup suatu bank. Bank tanpa adanya dana tidak akan mampu melaksanakan kegiatan apapun, oleh karena itu dana yang dimiliki oleh bank perlu dikelola dengan sebaik-baiknya. Dana merupakan uang tunai atau aktiva lainnya yang segera dapat diuangkan untuk maksud tertentu. Didalam suatu bank pada hakekatnya dana mempunyai pengertian yang sama dengan modal. Modal yang dimaksud disini adalah modal yang dapat menjelma dalam berbagai fasilitas harta tetap seperti tanah, gedung, rumah, inventaris kantor dan mesin-mesin serta fasilitas uang maupun sumber-sumber lainnya yang dapat digunakan dalam menunjang aktivitas operasional.

Pengertian Pengalokasian Dana Bank (I Gusti Ayu Purnamawati, Gede Adi Yuniarta, Ni luh Gede Erni Sulindawati, 2014 : 95).

Pengalokasian Dana Bank merupakan proses pengelolaan dana (Perencanaan, Pengalokasian dan Pengawasan Dana) baik pada aspek penghimpunan maupun penyaluran dana masyarakat guna mendapatkan keuntungan baik bagi masyarakat atau nasabah, maupun keuntungan bagi bank.

Sedangkan menurut (Marala, $193 ; 23$ ) yang dimaksud dengan dana dalam suatu bank adalah sejumlah uang yang dipercayakan oleh masyarakat atau pihak ketiga atau nasabah perusahaan atau perorangan kepada pihak bank, baik uang yang berasal dari pemilik modal maupun pihak ketiga lainnya untuk dimanfaatkan menurut cara-cara yang lazim digunakan dalam dunia perbankan pada umumnya. 
Dana bagi Bank merupakan dana yang mengendap dan tidak dapat diambil oleh pemiliknya sekurang-kurangnya selama satu hari, dan pada umumnya dana bank lebih banyak berasal dari simpanan masyarakat, dibanding dengan dana yang berasal dari modal sendiri. Dana yang berasal dari masyarakat dapat dikumpulkan dengan penyimpanan terutama dalam bentuk Rekening Giro, Deposito dan Tabungan. Semakin besar jumlah dana yang disimpan oleh masyarakat di bank, semakin besar pula kepercayaan yang diberikan masyarakat kepada bank, demikian pula sebaliknya.

Bagi sektor perbankan adanya dana dari pihak ketiga merupakan potensi utama untuk melaksanakan aktivitasnya. Bank Umum Pemerintah dananya berasal dari keuangan negara, sedangkan bank-bank swasta berasal dari saham para pendiri yang disetor sebagai permulaan modal kerja, potensi dari suatu bank tidak lain terletak pada kemampuan bank tersebut untuk dapat menarik dana yang beredar di dalam masyarakat mengingat modal sendiri sangatlah terbatas jumlahnya.

\section{Pengertian Bank}

Bank adalah suatu lembaga keuangan yang bergerak di bidang kepercayaan dalam arti sebagai media perantara keuangan antara debitur dengan kreditur. Bila dilihat dari hal ini berarti fungsi bank mencakup tiga kriteria hal pokok yaitu ; bank sebagai pengumpul dana, bank sebagai penjamin kreditur dan bank sebagai penanggung risiko interest rate dari tingkat suku bunga. Uraian diatas adalah pengertian bank secara umum yang menggambarkan fungsi bank sebagai pengumpul dana dari masyarakat.

Sedangkan pengertian bank menurut Undang-Undang Perbankan Nomor 10 tahun 1998 adalah Badan usaha yang menghimpun dana dari masyatrakat dalam bentuk simpanan dan menyalurkannya kepada masyarakat dalam kredit atau bentuk-bentuk lainnya dalam rangka meningkatkan taraf hidup rakyat banyak.
Sedangkan Pendapat para ahli perbankan mengemukakan definisi bank adalah sebagai berikut :

1. Menurut Anwari, Bank adalah Suatu badan usaha yang bertujuan memuaskan kebutuhan kredit, baik dengan alat-alat atau pembayayan sendiri dengan uang yang diperolehnya dari orang lain maupun dengan jalan memperedarkan alat-alat penukaran berupa uang giral yang diterbitkan oleh bank komersial.

2. Menurut Hasibuan, Bank adalah Lembaga perbankan keuangan pencipta uang, pengumpul dana dan pemberi kredit, mempermudah pembayaran dan penagihan, stabilisator moneter dan dinamisator pertumbuhan perekonomian.

3. Menurut Simorangkir, Bank adalah Suatu jenis lembaga keuangan yang melaksanakan berbagai macam jasa seperti memberi pinjaman, mengedarkan mata uang, pengawasan terhadap mata uang, bertindak sebagai tempat penyimpanan benda-benda berharga, membiayai perusahaan dan lalu lintas pembayaran.

Jadi bank merupakan lembaga keuangan yang mendorong pertumbuhan perekonomian nasional, usaha bank bukan sebagai penyimpan dan pemberi kredit saja, tetapi juga pencipta alat-alat pembayaran, stabilitas moneter dan dinamisator pertumbuhan perekonomian suatu perdagangan international antar negara.

Sesuai Undang-Undang Perbankan Nonor 10 Tahun 1998 Pasal 1 bahwa dalam UndangUndang ini yang dimaksud dengan :

a. Perbankan adalah Segala sesuatu yang menyangkut tentang bank, mencakup pembangunan, kegiatan usaha serta cara dan proses dalam melaksanakan kegiatan usaha.

b. Bank Umum adalah Bank yang melaksanakan kegiatan usaha secara konvensional dan atau berdasarkan prinsip syariah yang dalam kegiatannya memberikan jasa dalam lalu lintas pembayaran. 
c. Bank Perkreditan Rakyat adalah Bank yang melaksanakan kegiatan usaha secara konvensional atau berdasarkan prinsip syariah yang dalam kegiatannya tidak memberikan jasa dalam lalu lintas pembayaran.

\section{Manajemen Dana Bank.}

Sesuai dengan upaya pemerintah dalam hal penyimpanan dana program pembangunan dewasa ini, pemupukan dana masyarakat sangatlah diperlukan mengingat peranan simpanan penting bagi arus uang yang beredar dan untuk mengendalikan tingkat laju inflasi. Operasional bank pada umumnya diarahkan untuk menghimpun dana masyarakat dan mengelolanya seefektif mungkin.

Manajemen Bank dalam arti luas menurut Sinungan adalah Sebagai suatu proses pengelolaan, penghimpunan dana dari masyarakat ke dalam bank dan pengalokasian demi kepentingan bersama pada umumnya, serta pemupukan sumber daya yang tersedia demi mencapai rentabilitas bank yang sesuai dengan peraturan.

Adapun Manajemen Dana Bank Meliputi :

1. Aktivitas operasional bank dalam rangka menghimpun atau pemupukan dana masyarakat.

2. Aktivitas bank untuk menjaga kepercayaan masyarakat dengan penyediaan uang tunai bagi kepentingan masyarakat penyimpan.

3. Penempatan atau pengalokasian dana dalam bentuk kredit sebagai usaha pelayanan pinjaman yang diperlukan masyarakat yang bersifat jangka pendek dan panjang secara tunai demi terciptanya profitabilitas.

4. Pengelolaan bank agar berfungsi dengan baik.

Dalam kaitannya dengan aktivitas pemupukan dana dalam dunia perbankan, aktivitas ini diwujudkan dengan mengerahkan usaha bank berupa penghimpunan dana-dana yang menganggur (Idle Funds) yang ada di masyarakat. Dalam hal ini bank dituntut untuk menyediakan jasa-jasa dalam bentuk simpanan se- perti giro, tabungan, deposito dan jenis produk lainnya yang dipersamakan dengan itu. Untuk menghimpun dana dari masyarakat, bank mempunyai berbagai penampilan yang menarik guna menjaga kepercayaan masyarakat pada umumnya agar tidak terjadi kebingungan dalam menyimpan dananya kepada bank. Keterkaitan antara adanya kebijakan pemerintah dan peraturan lainnya mendorong bank agar berusaha menjadi mitra usaha kerja masyarakat yang dapat dipercaya. Keterbatasan bantuan yang diberikan oleh pemerintah sudah barang tentu tidak semua sektor mendapat bantuan pembiayaan, untuk mengatasi hal ini maka dibutuhkan pihak swasta sebagai tempat penyediaan dana langsung yang dibutuhkan guna membiayai pembangunan dan usaha demi tercapai suatu peningkatan di semua sektor industri dan non industri. Oleh karena itu didiriakn bank sebagai lembaga keuangan yang menghimpun dana dari masyarakat.

Menyadari pentingnya peranan perbankan dalam pembangunan, maka pemerintah mengeluarkan beberapa kebijakan sektor perbankan. Kebijakan tersebut ditujukan kepada bank dan pihak debitur yang beroperasi sesuai dengan kepentingan dan fungsinya sebagai lembaga keuangan. Salah satu fungsi bank adalah membantu pemerintah didalam melaksanakan administrasi keuangan negara serta mengawasi kebijakan pemerintah dalam bidang moneter perbankan, sehingga dengan adanya sistem perbankan yang sehat akan mendorong perekonomian dan moneter makin stabil dan mantap serta pembangunan berjalan dengan baik sesuai dengan rencana..

\section{Manajemen Pembelanjaan.}

Tujuan Manajemen Pembelanjaan Keuangan dan Tugas Pokok Manajer Keuangan (Fred J.Weston) adalah Memaksimumkan nilai perusahaan bermakna lebih luas dari pada memaksimumkan laba. Pernyaan ini dapat diterima kebenarannya atas dasar beberapa alasan, Pertama memaksimumkan nilai berarti 
mempertimbangkan pengaruh waktu terhadap nilai uang. Dana yang diterima pada tahun ini akan bernilai lebih tinggi dari pada dana yang diterima sepuluh tahun yang akan datang.

Kedua memaksimumkan nilai berarti mempertimbangkan berbagai risiko terhadap arus pendapatan perusahaan.

Ketiga mutu arus dana yang diharapkan diterima dimasa yang akan datang mungkin beragam. Gambaran laba perusahaan dapat sangat bervariasi bergantung pada konversi dan prinsip-prinsip akuntansi yang digunakan.

Sedangkan tugas pokok dari manajemen keuangan adalah suatu keputusan tentang investasi, pembiayaan dari kegiatan usaha dan pembagian deviden, pembayaran deviden berarti memutuskan bagaimana perusahaan membayar imbalan kepada investor. Adapun tugas pokok seorang manajer keuangan adalah merencanakan untuk memperoleh dana dan menggunakan dana tersebut untuk memaksimumkan nilai perusahaan. Untuk melaksanakan tugas tersebut manajer keuangan harus melakukan beberapa kegiatan yang menyangkut empat aspek yaitu :

1. Perencanaan dan peramalan dana bagi manajer keuangan harus ikut bekerjasama dengan para manajer lain yang ikut bertanggung jawab atas perencanaan umum perusahaan.

2. Keputusan investasi dan pembiayaan dalam perusahaan yang berhasil biasanya mengalami pertumbuhan penjualan yang tinggi serta memerlukan dukungan penambahan investasi dari perusahaan.

3. Manajer keuangan harus bekerjasama dengan manajer lain di perusahaan agar perusahaan dapat beroperasi seefisien mungkin.

4. Penggunaan pasar uang dan pasar modal harus bagaimana manajer keuangan menghubungkan antara perusahaan dengan pasar uang, dimana dana dapat diperoleh dan surat berharga perusahaan dapat diperdagangkan.
Berdasarkan uraian diatas jelas bahwa fungsi manajemen pembelanjaan terdapat di dalam tugas manajer keuangan. Perkembangan suatu perusahaan secara umum dapat diketahui bahwa masalah pembelanjaan, disamping masalah-masalah lainnya seperti marketing, produksi dan personalia merupakan masalah sentral yang ada dalam perusahaan untuk mencapai tujuan perusahaan yang telah ditentukan. Fungsi pembelanjaan tidak dapat dipisahkan dengan fungsi lainnya dalam perussahaan. Kegagalan dalam upaya mndapatkan dana misalnya akan dapat menghemat pembelian bahan mentah yang selanjutnya dapat menghemat produksi.

Fungsi pembelanjaan pun mengalami perkembangan dari waktu ke waktu, dari awal tahun sembilan belas lima puluhan fungsi utama dari pembelanjaan adalah mendapatkan dana, kemudian berkembang memperhatikan masalah penggunaan dana, hingga akhirnya masalah pembelanjaan kini tercakup dalam tugas manajer keuangan yang dihadapkan pada persoalanpersoalan mengenai operasi perusahaan yaitu :

a. Berapa besarnya perusahaan yang seharusnya dan berapa kecepatan pertumbuhan yang seharusnya.

b. Dalam bentuk apa aktiva dipertahankan oleh perusahaan.

c. Bagaimana komposisi hutang yang seharusnya.

d. Pengertian Manajemen Pembelanjaan dalam arti luas (Riyanto) adalah sebagai berikut : "Pembelanjaan meliputi aktivitas perusahaan yang bersangkutan dalam usaha mendapatkan dana yang dibutuhkan oleh perusahaan beserta usaha untuk menggunakan dana tersebut se-efisien mungkin".

Hal diatas mengemukakan bahwa pembelanjaan mempunyai fungsi ganda, yaitu keputusan tentang investasi dan keputusan tentang pembelanjaan atau manajemen dana, dengan tujuan memaksimumkan nilai perusahaan atau memakmurkan para pemegang saham. Sementara itu bila ditinjau dari pemupukan dan peng- 
gunaan modal pembelanjaan mempunyai dua pengertian yaitu :

a. Pembelanjaan aktif yakni dilihat dari perusahaan yang memiliki uang atau modal untuk diserahkan kepada perusahaan lain atau ditanamkan dalam perusahaan sendiri. Atau dalam arti luas yaitu semua usaha untuk menanamkan dana yang ada dalam perusahaan dengan cara se-efisien mungkin.

b. Pembelanjaan pasif yakni bagaimana perusahaan membutuhkan dana perusahaamn yang meminta atau manarik dana. Dengan cara bagaimana suatu perusahaan tersebut dapat memperoleh modal yang dibutuhkan dengan syarat yang paling menguntungkan. Hakekat pembelanjaan itu sendiri adalah menyangkut keseimbangan finansial di dalam suatu perusahaan. Dengan demikian pembelanjaan berarti mengadakan keseimbangan antara aktiva dan pasiva. Dan di dalam mencari keseimbangan tersebut pada jenis perusahaan yang berbeda akan berbeda pula perlakuannya. Pada perusahaan kredit (financial corporation) misalnya, hal ini dimulai dengan menentukan besarnya ataui susunan aktiva, dengan memperhatikansyarat-syaratnya. Setelah itu barulah ditentukan jumlah serta susunan aktiva yang disesuailan dengan jumlah dan susunan pasiva tersebut, sehingga akhirnya dapat menyusun struktur kekayaan yang sebaik-baiknya. Sedangkan pada perusahaan yang bukan financial corporation diutamakan lebih dahulu adalah masalah penentuan susunan aktiva yang diperlukan untuk melaksanakan produksi yang direncanakan. Setelah itu barulah kita menentukan jumlah dan susunan pasiva dengan menyesuaikannya dengan jumlah dan susunan aktiva, sehingga akhirnya kita mempunyai struktur modal yang sebaik-baiknya.

Untuk mencapai keseimbangan finansial di dalam perusahaan, maka pembelanjaan dibagi menjadi beberapa jenis yakni :
a. Pembelanjaan normal.
b. Pembelanjaan yang kurang cukup.
c. Pembelanjaan yang berlebihan.

Ditinjau dari sumber dana pembelanjaan dapat dibedakan menjadi :

1. Pembelanjaan dari luar perusahaan yang merupakan bentuk dari pembelanjaan dimana usaha pemenuhan kebutuhan modal diambil dari sumber modal yang berada di luar perusahaan.

Dan pembelanjaan dari luar perusahaan ini terdiri dari :

a. Pembelanjaan sendiri yang pemenuhan modalnya berasal dari pemilik atau calon pemilik, peserta dan pengambil bagian.

b. Pembelanjaan asing yang pemenuhan kebutuhan modalnya berasal dari reditur yang bersangkutan dan merupakan hutang modal.

2. Pembelajaan dari dalam perusahaan yang merupakan bentuk pembelanjaan dimana kebutuhan modal tidak diambilkan dari luar perusahaan, melainkan dari dana yang berbentuk atau dihasilkan sendiri oleh perusahaan.

Pembelanjaan dari dalam perusahaan ini terdiri dari :

a. Pembelanjaan intern yang menggunakan laba cadangan dan laba tidak dibagi.

b. Pembelanjaan intensif yang dijalankan dengan menggunakan penyusunan aktiva tetap yang sementara belum digunakan untuk mengganti aktiva tetap yang lama.

\section{Laporan Keuangan Bank dan Pengukuran Dalam Nilai Uang.}

Laporan Keuangan Bank harus disajikan dalam mata uang Rupiah. Dalam hal ini bank memiliki Aktiva, Kewajiban dan Komitmen serta Kontijensi dalam valuta asing, harus dijabarkan kedalam mata uang Rupiah dengan menggunakan kurs tengah yang berlaku pada tanggal laporan. Untuk modal yang disetor dalam mata uang asing dijabarkan dengan menggunakan kurs konversi Bank Indonesia pada saat modal 
disetor. Kurs Tengah adalah kurs jual ditambah kurs beli Bank Indonesia dibagi dua. Dalam hal kurs mata uang asing tidak tersedia di Bank Indonesia, digunakan kurs jual ditambah kurs beli bank yang bersangkutan dibagi dua. Bank wajib mengungkapkan posisi devisa neto aktiva dan kewajiban dalam valuta asing yang masih terbuka yang sering disebut dengan laporan posisi devisa neto (net open position)

Untuk memenuhi kepentingan berbagai pihak, laporan keuangan bank harus disusun berdasarkan Standar Akuntansi Keuangan Laporan Keuangan Bank terdiri dari :

a. Neraca

Dalam penyajiannya Aktiva dan Kewajiban dalam neraca bank tidak dikelompokkan menurut lancar dan tidak lancar (unclassified), namun sedapat mungkin tetap disusun menurut tingkat likuiditas dan jatuh tempo.

b. Laporan Laba-Rugi

Laporan laba-rugi bank wajib disusun sedemikian rupa agar dapat memberikan gambaran mengenai hasil usaha bank dalam suatu periode tertentu. Dan laporan ini disususn dalam bentuk berjenjang (multiple step) yang menggambarkan pendapatan dan beban yang berasal dari kegiatan utama bank dan kegiatan lainnya.

c. Laporan Arus Kas

Laporan Arus kas sesuai dengan Pernyataan Standar Akuntansi Keuangan (PSAK) nomor 2, tentang Laporan Arus Kas, harus disusun berdasarkan konsep kas (cash consept) selama periode laporan.

d. Laporan Komitmen dan Kontijensi

Laporan Komitmen dan Kontijensi wajib disusun secara sistimatis, sehingga dapat memberikan gambaran mengenai posisi komitmen dan kontijensi, baik yang bersifat tagihan maupun kewajiban pada tanggal laporan.

Komitmen adalah suatu ikatan atau kontrak berupa janji yang tidak dapat dibatalkan (irrevocable) secara sepihak dan harus dilaksanakan apabila persyaratan yang disepakati bersama dipenuhi, seperti komitmen kredit, komitmen penjualan atau pembelian aktiva bank dengan syarat repurchase agreement (repo).

Kontijensi adalah tagihan atau kewajiban bank yang kemungkinan timbulnya tergantung pada terjadi atau tidak satu atau lebih peristiwa dimasa yang akan datang.

e. Catatan Atas Laporan Keuangan

Disamping hal-hal yang wajib diungkapkan dalam catatan atas laporan keuangan sebagaimana dijelaskan dalam SAK dan pernyataan ini, bank juga wajib mengungkapkan dalam catatan tersendiri mengenai posisi devisa neto menurut jenis mata uang serta aktivitas-aktivias lain seperti penitipan harta (custodianship) dan penyaluran kredit kelolaan.

f. Laporan Keuangan Gabungan dan Konsolidasian Perbankan.

Bank yang mempunyai kantor cabang atau kantor operasional lainnya, wajib menyusun laporan keuangan gabungan pada setiap tanggal laporan, yang meliputi seluruh kantornya baik di dalam negeri maupun di luar negeri.

\section{Pemakai dan Kebutuhan Informasi Laporan Keuangan.}

Pemakai laporan keuangan meliputi investor sekarang investor potensial, karyawan, pemberi pinjaman, pemasok dan kreditor usaha lainnya, pelkanggan, pemerintah serta lembaga-lembaganya dan masyarakat. Mereka menggunakan laporan keuangan untuk memenuhi beberapa kebutuhan informasi yang berbeda. Beberapa kebutuhan ini meliputi :

a. Investor

Penanam modal berisiko dan penasehat mereka berkepentingan dengan risiko yang melekat serta hasil pengembangan dari investasi yang mereka lakukan. Mereka membutuhkan informasi untuk membantu menentukan apakah harus menarik, 
menahan atau menjual investasi tersebut. Pemegang saham juga tertarik pada informasi yang memungkinkan mereka untuk menilai kemampiuan perusahaan untuk membeyar deviden.

b. Karyawan

Karyawan dan kelompok-kelompok yang mewakili mereka tertarik pada informasi mengenai stabilitas dan profitabilitas perusahaan. Mereka juga tertarik dengan informasi yang memungkinkan mereka untuk menilai kemampuan perusahaan dalam memberikan balas jasa dan kesempatan kerja.

c. Pemberi Pinjaman

Pemberi Pinjaman tertarik dengan informasi keuangan yang memungkinkan mereka untuk memutuskan apakan pinjaman serta bunganya dapat dibayar pada saat jatuh tempo.

d. Pemasok dan Kreditor Usaha Lainnya Pemasok dan kreditor usaha lainnya tertarik dengan informasi yang memungkinkan mereka untuk memutuskan apakah jumlah yang terhutang akan dibayar pada saat jatuh tempo. Kreditor usaha berkepentingan pada pada perusahaan dalam tenggang waktu yang lebih pendek dari pada pemberi pinjaman, kecuali kalau sebagai pelanggan utama mereka tergantung pada kelangsungan hidup perusahaan.

e. Pelanggan

Para pelanggan berkepentingan dengan informasi mengenai kelangsungan hidup perusahaan, terutama kalau mereka terlibat dalam pinjaman jangka panjang dengan atau tergantung pada perusahaan.

f. Pemerintah

Pemerintah dan berbagai lembaga yang berada di bawah kekuasaannya berkepentingan dengan alokasi sumber daya dan karena itu berkepentingan dengan aktivitas perusahaan. Mereka juga membutuhkan informasi untuk mengukur aktivitas perusahaan, menetapkan kebijakan pajak dan sebagai dasar untuk menyusun statistik pendapatan nasional.

g. Masyarakat

Perusahaan mempengaruhi anggota masyarakat dalam berbagai cara, misalnya perusahaan dapat memberikan kontribusi pada perekonomian nasional, termasuk jumlah orang yang dipekerjakan dan perlindungan kepada penanam modal domestik. Laporan keuangan dapat membantu masyarakat dengan menyediakan informasi kecenderungan (trend) dan perkembangan terakhir kemakmuran perusahaan serta rangkaian aktivitasnya.

Informasi yang disajikan dalam laporan keuangan bersifat umum, dengan demikian tidak sepenuhnya dapat memenuhi kebutuhan informasi setiap pemakai. Berhubung para investor (penanam dana) merupakan penanam modal berisiko ke perusahaan, maka ketentuan laporan keuangan yang memenuhi kebutuhan mereka juga akan memenuhi sebagian besar kebutuhan pemakai lain. Manajemen perusahaan memikul tanggung jawab utama dalam penyusunan dan penyajian laporan keuangan perusahaan. Manajemen juga berkepentingan dengan informasi yang disajikan dalam laporan keuangan meskipun memiliki akses terhadap informasi manajemen dan keuangan tambahan yang membantu dalam melaksanakan tanggung jawab perencanaan, pengendalian dan pengambilan keputusan. Manajemen memiliki kemampuan untuk menentukan bentuk dan isi informasi tambahan tersebut untuk memenuhi kebutuhan sendiri. Namun demikian pelaporan informasi semacam itu berada diluar ruang lingkup kerangka dasar ini. Bagaimanapun juga laporan keuangan yang diterbitkan berdasarkan pada informasi nyang digunakan manajemen tentang posisi keuangan, kinerja dan perubahan posisi keuangan.

\section{Tujuan Laporan Keuangan.}

Tujuan laporan keuangan adalah menyediakan informasi yang menyangkut posisi ke- 
uangan, kinerja dan perubahan posisi keuangan suatu perusahaan yang bermanfaat bagi sejumlah besar pemakai dalam pengambilan keputusan ekonomi. Laporan keuangan yang disusun untuk tujuan ini memenuhi kebutuhan bersama sebagian besar pemakai. Namun demikian laporan keuangan tidak menyediakan semua informasi yang mungkin dibutuhkan pemakai dalam pengambilan keputusan ekonomi karena secara umum menggambarkan pengaruh keuangan dari kejadian di masa lalu dan tidak diwajibkan untuk menyediakan informasi non keuangan.

Laporan keuangan juga menunjukkan apa yang telah dilakukan manajemen atau pertanggung jawaban manajemen atas sumber daya yang dipercayakan kepadanya. Pemakai yang ingin menilai apa yang telah dilakukan atau pertanggung jawaban manajemen berbuat demikian agar mereka dapat membuat keputusan ekonomi, keputusan ini mungkin mencakup misalnya keputusan untuk menahan atau menjual investasi mereka dalam perusahaan atau keputusan untuk mengangkat kembali atau mengganti manajemen.

\section{Sumber dan Penggunaan Dana.}

Sumber dan penggunaan dana yang sering disebut juga dengan aliran dana merupakan alat analisis keuangan yang sangat penting bagi manajer keuangan, para calon kreditur dan bank dalam menilai permintaan kredit yang diajukan. Dengan analisis ini akan dapat diketahui bagaimana perusahaan mengelola atau menggunakan dana yang dimilikinya. Dengan demikian bank akan mengetahui mengenai kebijaksanaan pembelajaan dari suatu perusahaan termasuk setiap perubahan pos-pos dalam aktiva dan modal kerja dalam neraca perusahaan.

Istilah yang digunakan dalam Sumber dan Penggunaan Dana (Riyanto), dalam artian yang sempit yaitu kas atau dalam artian yang lebih luas yakni sebagai modal kerja. Dan secara lebih rinci yaitu :

Sumber Dana.
Dana dalam arti kas adalah uang kas yang ada di perusahaan, baik di tangan maupun di bank. Adapun yang dimaksud sebagai sumber dana adalah :

a. Berkurangnya aktiva lancar selain kas, ini berarti bertambahnya dana atau kas. Berkurangnya persediaan barang, terjadi karena terjualnya barang tersebut dan hasil dari penjualan itu merupakan sumber dana atau kas bagi perusahaan. Berkurangnya piutang berarti bahwa piutang itu telah diterima dan penerimaan piutang merupakan dana yang diterima perusahaan. Demikian pula berkurangnya surat-surat berharga atau efek berarti bahwa efek itu terjual dan hasil penjualannya merupakan sumber dana atau kas bagi perusahaan.

b. Berkurangnya aktiva tetap, seperti halnya dengan berkurangnya aktiva lancar, maka berkurangnya aktiva tetap juga merupakan sumber dana atau kas. Berkurangnya aktiva tetap bruto berarti bahwa sebagian dari aktiva tetap itu dijual dan hasil penjualan merupakan sumber dana. Berkurangnya aktiva tetap netto berarti adanya depresiasi yang merupakan sumber dana.

c. Bertambahnya setiap jenis utang, bertambahnya utang baik utang lancar maupun utang jangka panjang merupakan sumber dana. Bertambahnya utang berarti penanaman dana yang diterima perusahaan.

d. Bertambahnya modal, misalnya disebabkan adanya emisi saham baru dan hasil dari penjualan saham baru merupakan sumber dana.

e. Adanya keuntungan dari operasi perusahaan, apabila perusahaan mendapatkan keuntungan bersih dari operasinya berarti bahwa ada tambahan dana bagi perusahaan.

Sedangkan bertambahnya sumber dana menurut Mulyono, dapat terjadi karena :

a. Bertambahnya akan jumlah pemegang rekening yang menyetor dananya kepada bank baik berupa rekening tabungan, giro maupun deposito. 
b. Adanya kegiatan bank yang mengakibatkan bertambahnya seperti :

- Transfer uang yang belum dicairkan oleh penerima.

- Transfer uang yang masih transit.

- Adanya setoran jaminan pembukaan letter of credit impor dan bank garansi

c. Ada donasi dana dari para pemilik saham.

d. Adanya saham-saham baru yang dijual.

e. Adanya laba yang diperoleh.

f. Adanya kenaikan kurs mata uang asing yang berada di bank.

\section{Penggunaan Dana.}

Tindakan yang akibatnya memperkecil jumlah dana dikatakan sebagai penggunaan dana. Pengunaan dana meliputi hal-hal sebagai berikut :

a. Bertambahnya aktiva lancar selain kas, hal ini dapat terjadi karena pembelian barang membutuhkan dana.

b. Bertambahnya aktiva tetap, bertambahnya aktiva tetap bruto dapat terjadi karena adanya pembelian aktiva.

c. Berkurangnya utang, berkurangnya utang baik utang lancar maupun utang jangka panjang dapat terjadi karena perusahaan telah melunasi atau mengangsur utangnya.

d. Berkurangnya modal, berkurangnya modal terjadi karena pemilik perusahaan mengambil kembali atau mengurangi modal yang ditanam dalam suatu perusahaan.

e. Pembayaran kas deviden, pembayaran kas deviden adalah penggunaan dana, kas deviden dibayarkan dari hasil keuntungan bersih sesudah pajak.

f. Adanya kerugian dari operasi perusahaan, timbulnya kerugian selama peride tertentu dapat disertai berkurangnya aktiva atau bertambahnya utang. Sedangkan dari bertambahnya utang merupakan sumber dana, tetapi dengan adanya kerugianmaka bertambahnya dana tersebut digunakan untuk menutupi kerugian, sehingga dengan adanya kerugian tersebut merupakan penggunaan dana.
Sedangkan dana untuk sektor perbankan akan berkurang disebabkan oleh (Mulyono) :

a. Bank menderita kerugian dalam transaksi yang dilakukan.

b. Diserapnya dana karena adanya perubahan-perubahan dalam pos-pos aktiva yaitu untuk pengadaan aktiva baru atau untuk pelunasan utang-utang lainnya.

c. Pembelian harta tetap dan inventaris.

d. Untuk pembiayaan biaya operasional dan biaya non operasional.

e. Terjadinya pembagian laba, pembayaran pajak, sumbangan dan pengeluaran lainnya.

\section{Dana Sebagai Modal Kerja.}

Sumber-sumber dana, dana dalam arti modal kerja dapat berasal dari (Riyanto) yaitu :

a. Berkurangnya aktiva tetap

b. Bertambahnya utang jangka panjang

c. Bertambahnya modal dan

d. Keuntungan dari operasi perusahaan.

Penggunaan dana, penggunaan dana dalam arti modal kerja (Riyanto) adalah :

a. Bertambahnya aktiva tetap.

b. Berkurangnya utang jangka panjang

c. Berkurangnya modal

d. Pembayaran kas deviden

e. Kerugian dalam operasi perusahaan.

\section{Rasio-Rasio Keuangan.}

Menurut (Djahidin ; 1992:96), Rasio dapat diartikan sebagai gambaran suatu hubungan dari dua unsur (suatu jumlah tertentu dengan jumlah yang lain) secara matematis, sehingga dapat mengetahui gambaran kepada penganalisa tentang baik atau buruknya suatu keadaan atau posisi keuangan suatu perusahaan terutama apabila angka rasio-rasio tersebut dibandingkan dengan angka-angka standar.

\section{Likuiditas.}

Dalam menganalisa dan menilai kemampuan suatu perusahaan untuk memenuhi kewajiban jangka pendek, faktor utama yang 
diperhatikan adalah masalah likuiditas. Sebab likuiditas berasal dari kata "likuid" yang berarti cair. Setiap kelompok dari aktiva lancar dalam neraca disusun dari atas ke bawah sesuai dengan tingkat likuiditasnya, yakni bahwa kekayaan yang diatas akan lebih cepat menjadi kas dari pada kekayaan yang dibawahnya. Yang dimaksud dengan Likuiditas (Riyanto, 1989 : 18) yaitu Berhubungan dengan masalah kemampuan perusahaan untuk memenuhi kewajiban finansialnya yang segara harus dipenuhi.

Sedangkan Rasio Likuiditas menurut (Djahidin, 1982:101) adalah ; Rasio untuk menganalisis dan menginterprestasikan posisi keuangan jangka pendek untuk mengetahui kemampuan perusahaan menyediakan alat-alat yang likuid (yang mudah dijual atau diuangkan) guna pengebalian utang-utang jangka pendek yang telah atau akan jatuh tempo.

Jadi suatu perusahaan yang mampu untuk memenuhi kewajiban keuangannya yang harus segera dipenuhi, dikatakan bahwa perusahaan tersebut adalah likuid dan sebaliknya yang tidak mampu memenuhi kewajibannya disebut illikuid. Sebuah bank dapat dikatakan likuid apabila (Muljono, $1992: 64$ ) adalah :

1. Bank tersebut memiliki cash assets sebesar kebutuhan yang akan digunakan untuk memenuhi likuiditasnya.

2. Bank tersebut memiliki cash assets yang leih kecil dari butir 1 (satu) diatas, tetapi yang bersangkutan juga mempunyai assets lainnya, (khususnya surat-surat berharga) yang dapat dicairkan sewaktu-waktu tanpa mengalami penurunan nilai pasarnya.

3. Bank mempunyai kemampuan untuk menciptakan cash assets baru melalui bentuk utang.

Tujuan dari memelihara minimum alat likuid menurut (Lapoliwa, 1993 :133) adalah untuk menghindari terjadinya over atau under likuid, memanfaatkan kelebihan dana untuk disalurkan kepada aktiva yang dapat menciptakan pendapatan.

\section{Sejarah Singkat Perusahaan}

Obyek penelitian untuk mendapatkan materi atau guna analisis dalam penelitian ini adalah pada PT Bank X (Persero), yang didirikan pada tanggal 11 April 1960 berdasarkan Peraturan Pemerintah Pengganti UU No.13 tahun 1960 tanggal 2 April 1960. Kemudian dengan Peraturan Menteri Keuangan No.29103/ BUM11 April 1960, Bank X ditetapkan untuk melanjutkan PT Escomto Bank yang telah dilikuidasi. Berdasarkan UU No.18 tahun 1968 tanggal 18 April 1968 Bank ditetapkan sebagai Bank Umum Milik Pemerintah yang tugas dan usahanya diarahkan kepada perbaikan ekonomi rakyat dan pembangunan nasional dengan melakukan usaha bank umum yang mengutamakan sektor pertambangan. Dan dalam perkembangan selanjutnya Bank $\mathrm{X}$ juga menangani sektor lain yang prospektif seperti sektor pertanian dalam arti luas terutama sektor kehutanan, perkebunan dan sektor perindustrian konstruksi serta perdagangan dan jasa.

Sebagai tindak lanjut berikutnya UU No.7 tanggal 25 Maret 1992, maka dengan Peraturan Pemerintah No.20 tanggal 29 April 1992 bentuk hukum Bank X disesuaikan menjadi Perusahaan Perseroan (Persero) sebagai pelaksanaan dari ketentuan tersebut tehitung mulai tanggal 31 Juli 1992, bentuk hukum Bank X berubah menjadi Perseroan Terbatas. Sebagai Bank Umum, PT Bank X (Persero) melaksanakan tugas-tugas perbankan dalam kegiatan pempukan dana, pemberian kredit dan pelayanan jasa-jasa perbankan seperti transaksi ekspor, impor dan jasa-jasa lainnya.

\section{Kebijakan Pengumpulan dan Pengerahan Dana.}

Kebijakan yang ditetapkan oleh PT BanX (Persero) dalam usaha menarik dana dari masyarakat dengan tujuan agar memperoleh dana sebanyak mungkin untuk membiayasi kredit yang diajukan oleh calon debitur/debitur. Kebijakan pengumpulan dana ini meliputi :

1. Mencari nasabah deposito golongan mene- 
ngah dan bawah, karena golongan ini pada umumnya kurang sensitif tehadap perubahan-perubahan kondisi ekonomi sehingga dana tersebut dapat disimpan di bank untuk waktu yang relatif lama.

2. Mencari nasabah giro dari berbagai sektor ekonomi dengan tujuan agar tidak terjadi penarikan dana pada saat bersamaan, ketika keadaan pada suatu sektor memburuk.

3. Deposito berjangka dapat dijadikan jaminan kredit.

4. Menarik dana di usahakan dari rekening giro karena merupakan dana yang lebih murah jika dibandingkan dengan deposito.

5. Dalam usaha menarik dana deposito berjangka, bank mempublikasikan tingkat bunga melalui iklan.

6. Memberikan kemudahan kepada nasabah untuk dapat menarik dan menyetor dananya di seluruh cabang.

7. Memberikan pelayanan tambahan yang berupa menerima setoran pajak, pembayaran gaji dan lainnya.

\section{HASIL DAN PEMBAHASAN}

Analisis Sumber dan Penggunaan Dana, Trend sebagaimana tercantum dalam Neraca menunjukkan bahwa pos-pos aktiva lancar tahun 1996 mengalami kenaikan sebesar 10,9 persen bila dibandingkan dengan tahun 1995. Dan apabila dibandingkan dengan tingkat pertumbuhan kewajiban lancar, maka masih lebih tinggi tingkat pertumbuhannya. Dimana tingkat pertumbuhan kewajiban lancar hanya mencapai 3,2 persen, namun semua itu tidak langsung menunjukkan bahwa telah terjadi kenaikan tingkat likuiditas karena secara total jumlah aktiva lancar tahun 1996 lebih besar dari jumlah kewajiban lancar. Aktiva lancar pada tahun 1996 yang tercantum dalam neraca berjumlah sebesar Rp.30.001.342 juta, sedangkan kewajiban lancar sebesar Rp.26.478.050 juta.

Sedangkan untuk trend aktiva lancar tahun 1997 bahkan mengalami kenaikan yang sangat tinggi yakni sebesar 33,1 persen, bila dibandingkan dengan aktiva lancar pada tahun 1996. Dan apabila dibandingkan dengan tingkat pertumbuhan kewajiban lancar, maka masih lebih tinggi, sebab kenaikan kewajiban lancar tahun 1997 bila dibandingkan dengan kewajiban lancar pada tahun 1996 adalah 32,0 persen. Secara nominal kenaikan aktiva lancar tahun 1997 bila dibandingkan dengan tahun 1996 naik sebesar Rp.9.938.263 juta, dan kewajiban lancar naik sebesar Rp.8.744.615 juta.

Kenaikan yang terjadi pada Aktiva Lancar Rp.2.958.076 juta atau sebesar 10,9 persen dari tahun 1995 ke tahun 1996 dari rekening kas naik sebesar Rp.37.720 juta atau 17,8 persen, rekening giro pada Bank Indonesia Rp.371.072 juta, rekening giro pada bank lain sebesar Rp.176.877 juta, penempatan pada bank lain sebesar Rp.848.508 juta dan kredit yang diberikan naik sebesar Rp.1.651.431 juta. Sedangkan untuk kenaikan Aktiva Lancar sebesar Rp.9.938.263 juta atau sebesar 33,1 persen dari tahun 1996 ke tahun 1997, adalah dari rekening kas sebesar Rp.68.953 juta, rekening giro pada Bank Indonesia naik sebesar Rp.484.032 juta, rekening giro pada bank lain naik sebesar Rp.188.144 juta, surat-surat berharga naik sebesar Rp.1.491.205 juta dan kredit yang diberikan naik sebesar Rp.8.777.343 juta

Apabila dilihat dari secara keseluruhan pada tingkat pertumbuhan assets yang ada di neraca, menunjukkan pertumbuhan yang tergolong pesat. Karena assets tahun 1995 menunjukkan sebesar Rp.29.579.597 juta tahun 1996 sebesar 32.357.965 juta atau naik sebesar 9,4 persen dan tahun 1997 sebesar Rp.43.490.825 juta, berarti peningkataanya sangat besar atau sekitar 34,4 persen, hal ini disebabkan makin meningkatnya tingkat kepercayaan masyarakat yang menambah dananya pada PT Bank X (Persero).

Analisis Sumber dan Penggunaan Modal Kerja.

Sumber modal kerja yang diperoleh pada tahun 1995 dan 1996 adalah sebesar Rp.3.378.808 juta dan penggunaan modal ker- 
ja berjumlah sebesar Rp.1.669.767 juta. Dari sumber dana dan penggunaan dana terdapat selisih antara sumber dan penggunaan modal kerja sebesar Rp.1.709.041 juta. Kenaikan modal kerja ini kalau ditelusuri adalah akibat ketidak keseimbangan antara tingkat kenaikan aktiva tetap dan inventaris di satu pihak dan kenaikan kewajiban jangka panjang di pihak lain. Dan bila kita lihat angka-angka kenaikan piutang jangka panjang ini digunakan untuk membiayai aktiva tetap.

Analisis Perubahan Likuiditas Dengan Tingkat Kemampulabaan, Pengukuran tingkat likuiditas suatu bank agak sulit untuk dirumuskan karena semakin likuid suatu bank, maka semakin tidak profitable bank tersebut dan sebaliknya. Dilihat dari analisis likuiditas (dengan membandingkan Utang Lancar dibagi Kewajiban Lancar), tahun 1995, 1996 dan 1997 PT Bank $\mathrm{X}$ (Persero) selalu mengalami kenaikan seperti terlihat dalam perhitungan sebagai berikut (dalam jutaan rupiah):

\begin{tabular}{|c|c|c|c|c|c|c|}
\hline \multirow{2}{*}{$\begin{array}{c}\text { Tahun } \\
1995\end{array}$} & 7.043 .266 & \multirow{2}{*}{$x$} & \multirow{2}{*}{$100 \%$} & \multirow[b]{2}{*}{$=$} & \multirow[b]{2}{*}{01,44} & \multirow[b]{2}{*}{ Persen } \\
\hline & 6.660 .387 & & & & & \\
\hline \multirow{2}{*}{$\begin{array}{c}\text { Tahun } \\
1996\end{array}$} & 30.001 .342 & \multirow{2}{*}{ X } & \multirow{2}{*}{$100 \%$} & \multirow{2}{*}{$=$} & \multirow{2}{*}{113,31} & \multirow{2}{*}{ Persen } \\
\hline & 26.478 .050 & & & & & \\
\hline \multirow{2}{*}{$\begin{array}{c}\text { Tahun } \\
1997\end{array}$} & 39.939 .605 & \multirow{2}{*}{$x$} & \multirow{2}{*}{$100 \%$} & \multirow{2}{*}{$=$} & \multirow{2}{*}{113,39} & \multirow{2}{*}{ Persen } \\
\hline & 35.222 .665 & & & & & \\
\hline
\end{tabular}

Dengan demikian tingkat likuiditas PT Bank X (Persero) menggambarkan dalam kondisi baik, karena mampu menghimpun dana yang siqnifikan dan dipercaya masyarakat.

Untuk analisis kemampulabaan yang merupakan gambaran suatu perusahaan dalam mencapai laba, (membandingkan antara Pendapatan Operasional dibagi dengan Modal Perusahaan) dapat dilihat dalam perhitungan sebagai berikut (dalam jutaan rupaih) :

\begin{tabular}{|c|c|c|c|c|c|c|}
\hline \multirow{2}{*}{ Tahun 1995} & 249.875 & \multirow{2}{*}{$x$} & \multirow{2}{*}{$100 \%$} & \multirow{2}{*}{$=$} & \multirow[b]{2}{*}{17,95} & \multirow{2}{*}{ Persen } \\
\hline & 1.391 .937 & & & & & \\
\hline \multirow{2}{*}{ Tahun 1996} & 301.838 & \multirow{2}{*}{$x$} & \multirow{2}{*}{$100 \%$} & \multirow{2}{*}{$=$} & \multirow[b]{2}{*}{19,36} & \multirow{2}{*}{ Persen } \\
\hline & 1.559 .346 & & & & & \\
\hline \multirow{2}{*}{ Tahun 1997} & 397.759 & \multirow{2}{*}{$x$} & \multirow{2}{*}{$100 \%$} & \multirow{2}{*}{$=$} & \multirow[b]{2}{*}{22,11} & \multirow{2}{*}{ Persen } \\
\hline & 1.799 .368 & & & & & \\
\hline
\end{tabular}

Dari hasil analisis diatas menggambarkan bahwa PT Bank X (Persero) 3 tahun berturutturut mampu memperoleh keuntungan dan selalu menunjukkan kenaikan walaupun tidak banyak, berarti hal ini manajemen mampu mengelola dana masyarakat yang dihimpun.

\section{Analisis Diskriminan.}

Untuk mengetahui tingkat kesehatan bank apakah bank tersebut dalam keadaan sehat, cukup sehat, kurang sehat dan tidak sehat bank akan melakukan penilaian dengan menggunakan aspek CAMEL (Capital Assets, Quality Management and Earning Liquidity), dari masing-masing aspek tersebut mempunyai bobot yang berbeda-beda. Adapun faktor-faktor yang dinilai dari aspek tersebut sebagai berikut :

1. Permodalan, komonen yang dinilai adalah Rasio Modal terhadap Aktiva Tertimbang Menurut Risiko (ATMR) dengan bobot risiko 25 persen.

2. Kualitas Aktiva Produktif, komponen yang dinilai adalah Rasio Aktiva Produktif yang diklasifikasikan terhadap Aktiva Produktif dengan bobot risiko 25 persen dan Rasio Penyisian Penghapusan Aktiva (PPA) terhadap aktiva produktif yang diklasifikasikan dengan bobot risiko 5 persen.

3. Manajemen, komponen yang dinilai adalah, manajemen umum dengan bobot risikpo 10 persen dan manajemen risiko dengan bobot risiko sebesar 15 persen.

4. Rentabilitas, komponen yang dinilai adalah rasio laba terhadap total asset dengan bobot risiko sebesar 5 persen dan rasio beban operasional terhadap pendapatan operasional dengan bobot risiko sebesar 5 persen.

5. Likuiditas, komponen yang dinilai adalah rasio kewajiban bersih call money terhadap aktiva lancar dengan bobot risiko sebesar 5 persen dan rasio kredit terhadap dana yang diterima dengan bobot risiko sebesar 5 persen. 
Sebagaimana diuraikan diatas bahwa keseimbangan usaha untuk mencapai profitabilitas harus mempertimbangkan unsur likuiditas. Apabila hal ini kurang dikelola dengan baik, maka perusahaan dapat mengalami penurunan kinerja yang akhirnya cenderung ke arah kebangkrutan. Dengan demikian penulis menganalisa kondisi keuangan pada PT Bank $\mathrm{X}$ (Persero) dari segi Likuiditasnya dan dalam hal ini kiranya relevan untuk menganalisis posisi keuangan dengan menggunakan model discriminant analysys untuk mengukur tingkat kebangkrutan. Pada tahun 1968 Altman menggunakan sampel sebanyak 66 perusahaan manufacturing yang sebagian sampel tersebut mangalami kebangkrutan. Peramalan kebangkrutan perusahaan ini adalah merupakan suatu model yang disebut dengan Analisis Diskriminan (Discriminant Analysys). Satu tahun sebelum perusahaan itu bangkrut menurut laporan keuangannya terdapat 22 rasio keuangan dimana 5 diantaranya ditemukan memberikan banyak kontribusi pada model prediksinya (Weston and Copeland).

Berikut Hasil Analisis Diskriminan yang terdapat pada PT Bank X (Persero) adalah sebagai berikut (dalam jutaan rupiah) :

\begin{tabular}{|c|c|c|c|c|c|}
\hline \multirow{2}{*}{$x_{1}$} & \multirow{2}{*}{$=$} & Modal Kerja & \multirow{2}{*}{$x$} & \multirow{2}{*}{$100 \%$} & \\
\hline & & Harta & & & \\
\hline & \multirow{2}{*}{$=$} & 4.716 .940 & \multirow{2}{*}{$=$} & \multirow{2}{*}{10,85} & \multirow{2}{*}{ Persen } \\
\hline & & 43.490 .825 & & & \\
\hline \multirow{4}{*}{$x_{2}$} & \multirow{2}{*}{$=$} & Laba Ditahan & \multirow{2}{*}{$x$} & \multirow{2}{*}{$100 \%$} & \\
\hline & & Harta & & & \\
\hline & \multirow{2}{*}{$=$} & 381.748 & \multirow{2}{*}{$=$} & \multirow{2}{*}{0,88} & \multirow{2}{*}{ Persen } \\
\hline & & 43.490 .825 & & & \\
\hline \multirow{4}{*}{$x_{3}$} & \multirow[t]{2}{*}{$=$} & $\begin{array}{c}\text { Laba Sebelum Bunga \& } \\
\text { Pajak }\end{array}$ & \multirow[t]{2}{*}{$x$} & \multirow[t]{2}{*}{$100 \%$} & \\
\hline & & Harta & & & \\
\hline & \multirow{2}{*}{$=$} & 397.759 & \multirow{2}{*}{$=$} & \multirow{2}{*}{0,91} & \multirow{2}{*}{ Persen } \\
\hline & & 43.490 .825 & & & \\
\hline \multirow{4}{*}{$X_{4}$} & \multirow{2}{*}{$=$} & Nilai Pasar Modal Sendiri & \multirow{2}{*}{$x$} & \multirow{2}{*}{$100 \%$} & \\
\hline & & Nilai Buku Utang & & & \\
\hline & \multirow{2}{*}{$=$} & 43.490 .825 & \multirow{2}{*}{$=$} & \multirow{2}{*}{123,47} & \multirow{2}{*}{ Persen } \\
\hline & & 35.222 .665 & & & \\
\hline \multirow{4}{*}{$X_{5}$} & \multirow{2}{*}{$=$} & Penjualan & \multirow{2}{*}{$X$} & \multirow{2}{*}{ (kali) } & \\
\hline & & Harta & & & \\
\hline & & 4.051.299 & & & \\
\hline & & 43.490 .825 & & J & Nain \\
\hline
\end{tabular}

$$
\mathrm{Z}=0,012 \mathrm{X} 1+0,014 \mathrm{X} 2+0,033 \mathrm{X} 3+0,006
$$
$\mathrm{X} 4+0,999 \mathrm{X} 5$

$Z=0,12 \times(10,85)+0,14 \times(0,88)+0,033$ $\mathrm{x}(0,91)+0,006 \mathrm{x}(123,47)+0,999 \mathrm{x}(0,9)=3,1$

$\mathrm{Z}=$ Merupakan indeks menyeluruh (overall index) yang melebihi 2,99 atau $Z>2,99$. Hal ini berarti hasil analisis diskriminan mebuktikan bahwa PT Bank X (Persero) dinyatakan dalam keadaan sehat.

\section{LAPORAN KEUANGAN PT BANK X (PER- SERO)}

PT BANK X (PERSERO)

NERACA KONSOLIDAS TAHUN 1995, 1996 DAN 1997

(Dalam Jutaan Rupiah)

\begin{tabular}{|c|c|c|c|}
\hline Keterangan & $31 / 12 / 1995$ & $31 / 12 / 1996$ & $31 / 12 / 1997$ \\
\hline \multicolumn{4}{|l|}{ AKTIVA } \\
\hline 1. Kas & 212.386 & 250.106 & 319.059 \\
\hline $\begin{array}{l}\text { 2. Giro Pada Bank } \\
\text { Indonesia }\end{array}$ & 187.972 & 559.044 & 1.043.076 \\
\hline 3. Giro Pada Bank Lain & 332.050 & 508.927 & 697.071 \\
\hline $\begin{array}{l}\text { 4. Penempatan Pada } \\
\text { Bank Lain } \\
\end{array}$ & 2.946 .126 & 3.794 .634 & 2.723 .220 \\
\hline $\begin{array}{l}\text { 5. Surat-Surat } \\
\text { Berharga }\end{array}$ & 2.267 .591 & 2.140 .059 & 3.631 .264 \\
\hline $\begin{array}{l}\text { 6. Kredit Yang } \\
\text { Diberikan }\end{array}$ & 21.097.141 & 22.748 .572 & 31.525 .915 \\
\hline Jumlah Aktiva Lancar & 27.043 .266 & 30.001 .342 & 39.939 .605 \\
\hline 7. Penyertaan & 76.995 & 118.146 & 51.472 \\
\hline $\begin{array}{l}\text { 8. Pendapatan Yang } \\
\text { Akan Diterima } \\
\end{array}$ & 90.389 & 105.956 & 302.212 \\
\hline $\begin{array}{l}\text { 9. Biaya Dibayar } \\
\text { Dimuka } \\
\end{array}$ & 112.265 & 116.701 & 164.414 \\
\hline 10. Aktiva Tetap & 248.183 & 303.448 & 418.223 \\
\hline $\begin{array}{l}\text { 11. Aktiva Sewa Guna } \\
\text { Usaha }\end{array}$ & & 779 & 710 \\
\hline 12. Aktiva Lain-Lain & 2.008 .799 & 1.711 .593 & 2.614 .189 \\
\hline JUMLAH AKTIVA & 29.579 .897 & 32.357 .965 & 43.490 .825 \\
\hline \multicolumn{4}{|c|}{ KEWAJIBAN DAN MODAL } \\
\hline 1. Giro & 2.961 .174 & 3.197 .680 & 4.088.978 \\
\hline 2. Tabungan & 2.250 .174 & 2.695 .870 & 3.494 .670 \\
\hline 3. Deposito Berjangka & 9.330 .246 & 9.849 .866 & 16.720 .134 \\
\hline 4. Sertifikat Deposito & 681.523 & 811.250 & 303.363 \\
\hline $\begin{array}{l}\text { 5. Surat Berharga Yang } \\
\text { Diterbitkan }\end{array}$ & 1.097 .546 & 804.346 & 465.380 \\
\hline $\begin{array}{l}\text { 6. Pinjaman Yang } \\
\text { Diterima }\end{array}$ & 8.823 .003 & 8.693 .240 & 9.747 .854 \\
\hline $\begin{array}{l}\text { 7. Pinjaman } \\
\text { Subordinasi }\end{array}$ & 506.721 & 425.798 & 402.286 \\
\hline $\begin{array}{l}\text { Jumlah Kewajiban Jk } \\
\text { Pendek }\end{array}$ & 25.650 .387 & 26.478 .050 & 35.222 .665 \\
\hline $\begin{array}{l}\text { 8. Beban Yang Masih } \\
\text { Harus Dibayar }\end{array}$ & 93.848 & 94.849 & 156.350 \\
\hline 9. Kewajiban Lain-Lain & 2.098 .840 & 3.826 .463 & 5.641 .743 \\
\hline 10. Modal Pinjaman & 311.580 & 321.705 & 627.750 \\
\hline 11. Hak Minoritas & 33.305 & 37.552 & 42.949 \\
\hline 12. Ekuitas : & & & \\
\hline
\end{tabular}




\begin{tabular}{|l|r|r|r|}
\hline a. Modal Disetor & 1.000 .000 & 1.000 .000 & 1.000 .000 \\
\hline \begin{tabular}{l} 
b. $\begin{array}{l}\text { Modal } \\
\text { Sumbangan }\end{array}$ \\
\hline c. $\begin{array}{l}\text { Selisih Pen- } \\
\text { jabaran Lap Keu }\end{array}$
\end{tabular} & - & 567.447 & 411.797 \\
\hline
\end{tabular}

PT BANK X (PERSERO)

LAPORAN LABA-RUGI KONSOLIDASI

TAHUN 1995, 1996 DAN 1997

(Dalam Jutaan Rupiah)

\begin{tabular}{|c|c|c|c|}
\hline Keterangan & $31-12-95$ & $31-12-96$ & $31-12-97$ \\
\hline \multicolumn{4}{|c|}{ PENDAPATAN \& BEBAN OPERASIONAL } \\
\hline \multicolumn{4}{|l|}{ 1. Pendapatan Bunga } \\
\hline \multicolumn{4}{|l|}{ a. Hasil Bunga } \\
\hline 1) Rupiah & 1.958 .615 & 2.063 .607 & 2.554 .476 \\
\hline 1) Valuta Asing & 638.365 & 679.603 & 1.359 .359 \\
\hline \multicolumn{4}{|l|}{$\begin{array}{l}\text { a. Provisi dan Komisi } \\
\text { Kredit }\end{array}$} \\
\hline 1) Rupiah & 102.910 & 83.828 & 115.761 \\
\hline 1) Valuta Asing & 8.648 & 16.131 & 21.703 \\
\hline $\begin{array}{l}\text { Jumlah Pendapatan } \\
\text { Bunga }\end{array}$ & 2.708 .538 & 2.843 .169 & 4.051 .299 \\
\hline \multicolumn{4}{|l|}{ 2. Beban Bunga } \\
\hline \multicolumn{4}{|l|}{ a. Beban Bunga } \\
\hline 1) Rupiah & 1.551 .880 & 2.095 .311 & 2.363 .605 \\
\hline 1) Valuta Asing & 560.850 & 601.578 & 971.063 \\
\hline $\begin{array}{c}\text { b. Beban Lainnya } \\
\text { Selain Beban Bunga }\end{array}$ & 5.994 & 40.910 & 7.507 \\
\hline Jumlah Beban Bunga & 2.118.724 & 2.737 .799 & 3.342 .175 \\
\hline $\begin{array}{l}\text { Pendapatan Bunga } \\
\text { Bersih }\end{array}$ & 589.814 & 105.370 & 709.124 \\
\hline \multicolumn{4}{|l|}{$\begin{array}{l}\text { 3. Pendapatan } \\
\text { Operasional Lainnya }\end{array}$} \\
\hline $\begin{array}{l}\text { a. Provisi dan Komisi } \\
\text { Selain Kredit }\end{array}$ & 23.455 & 123.608 & 108.287 \\
\hline $\begin{array}{l}\text { b. Pendapatan Valuta } \\
\text { Asing }\end{array}$ & 207.159 & 689.138 & 7.623 .483 \\
\hline c. Pendapatan Lainnya & 34.389 & 24.751 & 71.543 \\
\hline $\begin{array}{l}\text { Jumlah Pendapatan } \\
\text { Operasional Lainnya }\end{array}$ & 265.003 & 837.497 & 7.803 .313 \\
\hline \multicolumn{4}{|l|}{$\begin{array}{l}\text { 4. Beban Operasional } \\
\text { Lainnya }\end{array}$} \\
\hline $\begin{array}{l}\text { a. Berban Administrasi } \\
\text { dan Umum }\end{array}$ & 161.348 & 203.989 & 227.305 \\
\hline b. Beban Personalia & 239.992 & 261.123 & 333.426 \\
\hline c. PPAP & 143.452 & 87.595 & 417.794 \\
\hline d. Beban Lainnya & 65.211 & 85.953 & 7.148 .757 \\
\hline $\begin{array}{l}\text { Jumlah Beban } \\
\text { Operasional Laoinnya }\end{array}$ & 610.003 & 638.660 & 8.127 .282 \\
\hline $\begin{array}{l}\text { Pendapatan/Beban } \\
\text { Operasional Bersih }\end{array}$ & 244.814 & 304.207 & 385.155 \\
\hline \multicolumn{4}{|l|}{$\begin{array}{l}\text { Pendapatan/Beban Non } \\
\text { Operasional }\end{array}$} \\
\hline $\begin{array}{l}\text { 5. Pendapatan Non } \\
\text { Operasional }\end{array}$ & 5.285 & 13.882 & 14.071 \\
\hline $\begin{array}{l}\text { 6. Beban Non } \\
\text { Operasional } \\
\end{array}$ & 224 & 16.251 & 1.467 \\
\hline $\begin{array}{l}\text { Pendapatan/Beban Non } \\
\text { Operasional }\end{array}$ & 5.061 & $(2.369)$ & 12.604 \\
\hline $\begin{array}{l}\text { 7. Laba/Rugi Sebelum } \\
\text { Pajak Penghasilan }\end{array}$ & 249.875 & 301.838 & 397.759 \\
\hline
\end{tabular}

\begin{tabular}{|c|r|r|r|}
\hline $\begin{array}{c}\text { d. } \begin{array}{l}\text { Selisih Penilaian } \\
\text { Kembali AT }\end{array} \\
\text { e. Laba Ditahan }\end{array}$ & 1.524 & 1.524 & 1.524 \\
\hline $\begin{array}{l}\text { Jumlah Kewajiban \& } \\
\text { Modal }\end{array}$ & 29.579 .896 & 330.162 & 381.748 \\
\hline
\end{tabular}

\begin{tabular}{|l|r|r|r|}
\hline $\begin{array}{l}\text { 8. Taksiran Pajak } \\
\text { Penghasilan }\end{array}$ & 84.151 & 79.500 & 152.713 \\
\hline $\begin{array}{l}\text { 9. Laba Rugi Tahun } \\
\text { Berjalan }\end{array}$ & 165.724 & 222.338 & 245.046 \\
\hline $\begin{array}{l}\text { 10. Hak Minoritas } \\
\text { 11. Laba Ditahan Awal } \\
\text { Periode }\end{array}$ & 4.578 & - & 7.790 \\
\hline $\begin{array}{l}\text { 12. Deviden dan } \\
\text { Pembagian Laba Lainnya }\end{array}$ & 110.904 & 140.142 & 185.670 \\
\hline $\begin{array}{l}\text { 13. Laba Ditahan Akhir } \\
\text { Periode }\end{array}$ & 247.966 & 330.162 & 381.748 \\
\hline
\end{tabular}

PT BANK X (PERSERO)

LAPORAN PERUBAHAN MODAL KERJA

TAHUN 1995 DAN 1996

\begin{tabular}{|l|r|r|r|r|}
\hline $\begin{array}{l}\text { Unsur-Unsur Modal } \\
\text { Kerja }\end{array}$ & $\mathbf{3 1 / 1 2 / 1 9 9 5}$ & $\mathbf{3 1 / 1 2 / 1 9 9 6}$ & Naik & Turun \\
\hline Aktiva Lancar & & & & \\
\hline 1. Kas dan Bank & 732.408 & 1.318 .077 & 585.669 & \\
\hline $\begin{array}{l}\text { 2. Penempatan Pada } \\
\text { Bank Lain }\end{array}$ & 2.946 .126 & 3.794 .634 & 848.508 & \\
\hline $\begin{array}{l}\text { 3. Surat-Surat } \\
\text { Berharga }\end{array}$ & 2.267 .591 & 2.140 .059 & & 127.532 \\
\hline $\begin{array}{l}\text { 4. Kredit Yang } \\
\text { Diberikan }\end{array}$ & 21.097 .141 & 22.748 .572 & 1.651 .431 & \\
\hline Jumlah Aktiva Lancar & $\mathbf{2 7 . 0 4 3 . 2 6 6}$ & $\mathbf{3 0 . 0 0 1 . 3 4 2}$ & & \\
\hline & & & & \\
\hline Kewajiban Lancar & & & & \\
\hline 1. Giro & 2.961 .174 & 3.197 .680 & & 236.506 \\
\hline 2. Tabungan & 2.250 .174 & 2.695 .870 & & 445.696 \\
\hline 3. Deposito Berjangka & 9.330 .246 & 9.849 .866 & & 519.620 \\
\hline 4. Sertifikat Deposito & 681.523 & 811.250 & & 129.727 \\
\hline $\begin{array}{l}\text { 5. Surat Berharga } \\
\text { Yang Diterbitkan }\end{array}$ & 1.097 .546 & 804.346 & 293.200 & \\
\hline $\begin{array}{l}\text { 6. Pinjaman Yang } \\
\text { Diterima }\end{array}$ & 8.823 .003 & 8.693 .240 & & 129.763 \\
\hline $\begin{array}{l}\text { 7. Pinjaman } \\
\text { Subordinasi }\end{array}$ & 506.721 & 425.798 & & 80.923 \\
\hline $\begin{array}{l}\text { Jumlah Kewajiban } \\
\text { Lancar }\end{array}$ & 25.650 .387 & 26.478 .050 & & \\
\hline & & & & 1.709 .041 \\
\hline
\end{tabular}




\section{KESIMPULAN DAN SARAN \\ Kesimpulan}

Setelah penulis melakukan penelitian dan analisa, maka ada beberapa hal yang dapat kami simpulkan mengenai kondisi keuangan pada PT Bank X (Persero) adalah sebagai beikut :

1. PT Bank X (Persero) adalah suatu Perusahaan yang bergerak dalam bidang jasa perbankan yang didirikan pada tahun 1960 di Jakarta dengan nama Nederlandsch Indische Excompto Maatschappij, dan kemudian sejak tahun 1968, PT Bank X (Persero) ditetapkan menjadi Bank Umum Milik Pemerintah yang melakukan usaha Bank Umum dengan mengutamakan sektor pertambangan. Di samping itu juga melayani sektor-sektor lain yang prospektif seperti pertanian, perindustrian, perdagangan dan jasa-jasa. Kedudukan kantor PT Bank $\mathrm{X}$ (Persero) saat ini berada di Jalan $\mathrm{MH}$ Thamrin Nomor 5 Jakarta Pusat.

2. Sumber dana yang diperoleh terlihat mengalami peningkatan yang sangat berarti baik di tahun 1996 maupun pada tahun 1997. Hal ini menandakan besarnya kepercayaan masyarakat dan dunia bisnis khususnya perbankan pada PT Bank X (Persero).

3. Dilihat dari sudut likuiditas dan kemampulabaan, bahwa PT Bank X (Persero) lebih menekankan pada likuiditas dari pada kemampulabaan. Atau lebih mengutamakan kepercayaan kepada masyarakat dari pada keuntungan yang harus diperoleh.

4. Data dalam ikhtisar kegiatan usaha menggambarkan bahwa Loan to Deposit Ratio (LDR) pada tahun 1996 adalah sebesar 85,91persen, sedangkan pada tahun 1997 sebesar 89,5 persen. Ratio ini mengukur kredit yang diberikan terhadap nasabah, namun kemampulabaan yang di peroleh oleh PT Bank X (Persero) relatif kecil.

5. Hasil dari analisis diskriminan menunjukkan bahwa PT Bank X (Persero) mempunyai suatu kekuatan, dimana hasil analisisnya adalah $\mathrm{Z}=3,1$ dalam hal ini berarti hasil analisis diskriminan membuktikan bahwa PT Bank X (Persero) dinyatakan dalam keadaan sehat.

6. Dalam kondisi sekarang ini perbankan di Indonesia mengalami kesulitan untuk mengoperasikan dananya, karena tingkat suku bunga yang ditetapkan oleh Bank Indonesia dengan SBI-nya yang tinggi, mengakibatkan Bank Umum Pemerintah menetapkan suku bunga yang tinggi pula untuk para nasabahnya.

7. Dilihat dari Laporan Laba-Rugi antara tahun 1995, 1996 dan tahun 1997 menunjukkan bahwa hasil keuntungan yang diperoleh selalu menunjukkan kenaikan, maka apabila kondisi perbankan saat ini masih sama dengan tahun tersebut kami menyimpulkan bahwa PT Bamnk X (Persero) akan tetap sehat seiring dengan perbaikan sumber daya manusia yang ada.

\section{Saran}

Berdasarkan kesimpulan di atas, maka penulis mengajukan beberapa saran agar PT Bank X (Perseto) tetap eksis dan masyarakat tetap mempercayakan dananya maka kami menyampaikan hal-hal sebagai berikut :

1. Mengingat analisis antara perubahan likuiditas dengan tingkat kemampulabaan pada tahun 1995 ke tahun 1996 masing-masing mengalami kenaikan sebesar 11,84 persen dan 0,96 persen, dimana kemampulabaan lebih kecil bila dibandingkan dengan kenaikan likuiditas, maka sebaiknya PT Bank $\mathrm{X}$ (Persero) mengupayakan peningkatan kemampulabaan, karena modal yang ditanamkan masih memungkinkan untuk dapat dioperasikan guna menambah jumlah laba yang telah diperoleh tersebut.

2. Untuk mengantisipasi beban operasional yang tinggi, perlu mengadakan efisiensi di bidang beban operasional. Karena jika diperhatikan Loan to Deposit Ratio (LDR) pada tahun 1996 sebesar 85,91 persen dan tahun 1997 sebesar 89,5 persen, ini meru- 
pakan suatu prestasi pada bank pengguna dana, namun dibalik itu terjadi beban operasional yang membuat kurang efisien yang akan mengakibatkan penurunan laba perusahaan. Disamping itu juga adanya suatu kredit yang diberikan kepada nasabah perlu dilakukan secara selektif, sehingga dapat mengurangi persentase kredit macet.

3. Kekuatan yang dimiliki oleh PT Bank X (Persero) adalah merupakan modal dasar untuk dapat memenangkan peluang pasar yang ada. Oleh karena itu, kekuatan tersebut perlu dipertahankan keberadaanya.

4. PT Bank X (Persero) perlu melakukan perubahan formulasi tarif suku bunga antar kantor, sehingga dapat memotivasi cabangcabang untuk menghimpun dana dari masyarakat dan bisa mandiri dalam mengelola harta dan hutangnya.

5. Untuk menghidupkan atau meningkatkan kembali pertumbuhan di sektor perbankan, pemerintah melalui Bank Umum perlu menurunkan tingkat suku bunga, sehingga pertumbuhan perekonomian Indonesia dapat meningkat dan pada gilirannya dapat pula meningkatkan perbankan yang ada di Indonesia.

6. Hasil analisis ini menyimpulkan bahwa PT Bank X (Persero) harus berani menurunkan tingkat suku bunga yang saat ini dirasa sangat tinggi, yaitu melalui koordinasi dengan pemerintah. Tingkat suku bunga ynag tinggi berakibat tidak dapat menyehatkan perekonomian Indonesia, khususnya sektor perbankan yang pada gilirannya akan terjadi perubahan harga-harga akan menjadi tinggi, sehingga mengakibatkan daya beli masyarakat semakin melemah.

7. Sebagaimana diungkapkan sebelumnya bahwa penelitian ini terbatas pada suatu obyek penelitian yang dianalisis menggunakan model studi kasus. Hasil dari penelitian ini diharapkan dapat digunakan oleh peneliti berikutnya yang dapat menggunakan jumlah sampel yang lebih besar khu- susnya untuk melihat peranan sumber dan penggunaan dana di sektor perbankan. Dengan demikian permasalahan perbankan nasional yang dihadapi oleh Indonesia dewasa ini dapat memperoleh kontribusi untuk melakukan perbaikan dan peningkatan sektor perbankan.

8. Apabila dikaitkan dengan kondisi saat ini dengan perkiraan perekonomian baru akan membaik pada tahun 2000 kedepan, maka sebaiknya PT Bank X (Perserto) segera melakukan ekspansi dalam menyalurkan kreditnya kembali kepada perusahaan maupun perorangan, namun hal ini perlu juga adanya kehati-hatian.

\section{DAFTAR PUSTAKA}

I Gusti Ayu Purnamawati, Gede Adi Yuniarta, Ni luh Gede Erni Sulindawati, Akuntansi Perbankan Teori dan Soal Latihan, Penerbit Graha Ilmu, Jakarta 2014.

Kasmir, Bank dan Lembaga Keuangan Lainnya, Penerbit PT Raja Grafindo Persada, Jakarta Edisi Revisi 2014.

Hery, Akuntansi Aset, Liabilitas dan Ekuitas, Penerbit PT Gramedia Widiasarana Indonesia, Jakarta 2014.

Raja Andri Satriawan Surya, Akuntansi Keuangan Versi International Financial Reporting Standard Plus, Graha Ilmu Yogjakarta 2012

Hery, Akuntansi Intermediate, Akuntansi Keuangan Menengah, Lembaga Penerbit Fakultas Ekonomi Universitas Indonesia, Jakarta 2016.

Rahman Pura, Pengantar Akuntansi 1, Pendekatan Siklus Akuntansi, Penerbit Erlangga - Jakarta 2012.

Wiwin Yadiati, Abdulloh Mubarok, Kualitas Pelaporan Keuangan, Kajian Teoretis dan Empiris, Penerbit Kencana Jakarta 2017.

Walter T. Harrison JR, Charles T.Horngen, C.William Thomas, Themin Suwardy, Akuntansi Keuangan, International Financial Reporting Standards - IFRS, Penerbit Erlangga Jakarta 2014. 
Dahlan Siamat, Manajemen Lembaga Keuangan, Kebijakan Moneter dan Perbankan, Lembaga Penerbit Fakultas Ekonomi Universitas Indonesia, Jakarta 2005.

Selamet Riyadi, Banking Assets and Liability Management, Lembaga Penerbit Fakultas Ekonomi Universitas Indonesia, Jakarta 2003.

Ismail, Akuntansi Bank. Teori dan Aplikasi Dalam Rupiah, Penerbit Prenadamedia Group, Jakarta 2014.

V. Wiratna Sujarweni, Pengantar Akuntansi, Penerbit, Pustaka Baru Press, Yogyakarta 2016.

Slamet Sugiri Sodikin, Akuntansi Pengantar 2 Berbasis SAK ETAP 2009 Edisi keenam, Penerbit Unit Penerbit dan Percetakan STI Manajemen YKPN, Yogyakarta 2013.

Teguh Pudjo Muljono, Analisa Laporan Keuangan Untuk Perbankan, Penerbit Djambatan, Jakarta 1995.

Jongker Sihombing, Pengantar Funds Management Untuk Perbankan, Penerbit Institut Bankir Indonesia, Jakarta 1993

Bambang Riyanto, Dasar-Dasar Pembelajaan Perusahaan, Edisi Tiga, Yayasan Badan Penerbit Gajah Mada, Yogyakarta Tahun 1989.

Djuhaepah T. Marala, Manajemen Dana Perbankan, Jakarta 1993.

Lapoliwa N dan Daniel S Kusnadi, Akuntansi Perbankan, Akuntansi Transaksi Bank Dalam Valuta Rupiah, Edisi 5, Penerbit Institut Bankir Indonesia, Jakarta Tahun 2000.

Achmad Anwari, Praktek Perbankan di Indonesia, Jakarta 1993.

Soetisna RMD, Manajemen Keuangan (Managerial Finance), Jakarta 1996.

Teguh Pudjo Muljono, Aplikasi Akuntansi Manajemen Dalam Praktek Perbankan, Edisi Kedua, Penerbit BPFE, Yogyakarta 1994.

Djahidin Farid, Analisa Laporan Keuangan, Penerbit Ghalia Indonesia, Jakarta 1992.

Zaki Baridwan, Intermediate Accounting, Edisi Keenam, Penerbit BPFE, Yogyakarta Tahun 1990.
Simangunsong MP, Pokok-Pokok Analisis Laporan Keuangan, Edisi Kesatu, Penerbit Karya Utama, Jakarta 1991.

Munawir, Analisis Laporan Keuangan, Penerbit Liberty, Yogyakarta 1990.

Mucdarsyah Sinungan, Strategi Manajemen Bank Menghadapi Tahun 2000, Rineka Cipta, 1994.

Fred J.Weston dan Thomas E Copeland, $M a-$ najemen Keuangan, Edisi Kedelapan (Edisi Revisi), Penerbit Binarupa Aksara, Jakarta 1991. 
